\title{
Secret Messages in Enigmatic Playful Texts
}

\author{
Ricardo Gobato $^{1 *}$, Marcia Regina Risso Gobato ${ }^{1}$, Alireza Heidari ${ }^{2}$, Abhijit Mitra ${ }^{3}$ and Ibtihal Kadhim \\ Kareem Dosh ${ }^{4}$
}

${ }^{1}$ Green Land Landscaping and Gardening, Seedling Growth Laboratory, Brazil.

${ }^{2}$ Faculty of Chemistry, California South University, USA.

${ }^{3}$ Department of Marine Science, University of Calcutta, India.

${ }^{4}$ Department of Chemistry, Kufa University, Faculty of Education, Iraq.

*Corresponding author: Ricardo Gobato, Green Land Landscaping and Gardening, Seedling Growth Laboratory, Parana, Brazil

Received Date: March 09, 2020

Published Date: April 27, 2020

\begin{abstract}
Stenography and cryptography have been used for centuries to transmit, send, hide messages, communication between certain people, groups, governments, as the main objective to protect certain information. Hidden text and common text or in an image, etc. that only the sender and the receiver know them and how to decipher them. This work has a purpose of didactic, scientific and playful application in the use of shorthand and cryptography. The method applied here is random, manual, of fitting each word. Thus, the use of a simple ludic, informative, scientific, didactic "game" can contain secret, coded, directed information, to a specific individual, organization, etc. Thus carrying information in a secret character, which would hardly be discovered by any other individual, organization, etc.
\end{abstract}

\section{Introduction}

Stenography and cryptography have been used for centuries to transmit, send, hide messages, communication between certain people, groups, governments, as the main objective to protect certain information. Hidden, hidden text and common text or in an image, etc. that only the sender and the receiver know them and how to decipher them.

\section{Cryptography or cryptology (from Ancient Greek:

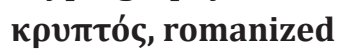

kryptós "hidden, secret"; and $\gamma \rho \alpha \dot{\varphi} \varphi \varepsilon เ v$ graphein, "to write", or

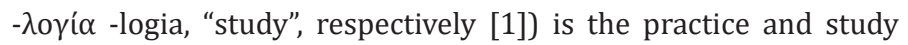
of techniques for secure communication in the presence of third parties called adversaries [2]. More generally, cryptography is about constructing and analyzing protocols that prevent third parties or the public from reading private messages [3]; various aspects in information security such as data confidentiality, data integrity, authentication, and non-repudiation [4] are central to modern cryptography. Modern cryptography exists at the intersection of the disciplines of mathematics, computer science, electrical engineering, communication science, and physics. Applications of cryptography include electronic commerce, chip-based payment cards, digital currencies, computer passwords, and military communications. Since the development of rotor cipher machines in World War I and the advent of computers in World War II, the methods used to carry out cryptology have become increasingly complex and its application more widespread [9].

Modern cryptography is heavily based on mathematical theory and computer science practice; cryptographic algorithms are designed around computational hardness assumptions, making such algorithms hard to break in practice by any adversary. It is theoretically possible to break such a system, but it is infeasible to do so by any known practical means. These schemes are therefore termed computationally secure; theoretical advances, e.g., improvements in integer factorization algorithms, and faster computing technology require these solutions to be continually adapted. There exist information-theoretically secure schemes that provably cannot be broken even with unlimited computing poweran example is the one-time pad-but these schemes are more difficult to use in practice than the best theoretically breakable but computationally secure mechanisms [5]. 
The growth of cryptographic technology has raised a number of legal issues in the information age. Cryptography's potential for use as a tool for espionage and sedition has led many governments to classify it as a weapon and to limit or even prohibit its use and export [6]. In some jurisdictions where the use of cryptography is legal, laws permit investigators to compel the disclosure of encryption keys for documents relevant to an investigation [7-9].

\section{Steganography}

It is the practice of concealing a file, message, image, or video within another file, message, image, or video. The word steganography comes from New Latin steganographia, which combines the Greek words steganós ( $\sigma \tau \varepsilon \gamma \alpha v o ́ \varsigma$ ), meaning "covered or concealed", and Latin -graphia meaning "writing" [9].

The first recorded use of the term was in 1499 by Johannes Trithemius in his Steganographia, a treatise on cryptography and steganography, disguised as a book on magic. Generally, the hidden messages appear to be (or to be part of) something else: images, articles, shopping lists, or some other cover text. For example, the hidden message may be in invisible ink between the visible lines of a private letter. Some implementations of steganography that lack a shared secret are forms of security through obscurity, and key-dependent steganographic schemes adhere to Kerckhoffs's principle [9-10].

The advantage of steganography over cryptography alone is that the intended secret message does not attract attention to itself as an object of scrutiny. Plainly visible encrypted messages, no matter how unbreakable they are, arouse interest and may in themselves be incriminating in countries in which encryption is illegal [11]. Whereas cryptography is the practice of protecting the contents of a message alone, steganography is concerned both with concealing the fact that a secret message is being sent and its contents.

Steganography includes the concealment of information within computer files. In digital steganography, electronic communications may include steganographic coding inside of a transport layer, such as a document file, image file, program or protocol. Media files are ideal for steganographic transmission because of their large size. For example, a sender might start with an innocuous image file and adjust the color of every hundredth pixel to correspond to a letter in the alphabet. The change is so subtle that someone who is not specifically looking for it is unlikely to notice the change.

Making text the same color as the background in word processor documents, e-mails, and forum posts. Using Unicode characters that look like the standard ASCII character set (the homograph spoofing attack). On most systems, there is no visual difference from ordinary text. Some systems may display the fonts differently, and the extra information would then be easily spotted, of course $[9,12]$.
Using hidden (control) characters, and redundant use of markup (e.g., empty bold, underline or italics) to embed information within HTML, which is visible by examining the document source. HTML pages can contain code for extra blank spaces and tabs at the end of lines, and colors, fonts and sizes, which are not visible when displayed. This work has a purpose of didactic, scientific and playful application in the use of shorthand and cryptography. The method applied here is random, manual, of fitting each word. Thus, the use of a simple ludic, informative, scientific, didactic "game" can contain secret, coded, directed information, to a specific individual, organization, etc. Thus carrying information in a secret character, which would hardly be discovered by any other individual, organization, etc. Here it is used in four different situations. His teaching, scientific employment and playful need not necessarily be used in the order which will be elucidated, may be in any order. Exemplified here are four specific situations, but could be any other.

\section{Methods}

The method applied here is random, manual, of fitting each word, used in the three different situations, one from the other. A table of dimensions $\mathrm{A}=\mathrm{Aij}=\mathrm{A} 28 \times 26$ is constructed, but you can have any other dimension, $A=A i j$, for $i=10$ to $n, j=10$ to $n$. Aii $=\mathrm{A} 10 \times 10$ is suggested as a minimum for increased difficulty of deciphering the secret, enigma message, etc. Because the higher $\mathrm{i}$ and $\mathrm{j}$ will be greater the difficulty to decipher the message. The secret message receiver must know the three situations used to determine the message. After solving the playful part, which is to find the words, that is, to solve the problem situation, in the three different situations presented here, the message will appear with the remaining letters, that is, that were not used in any word to be found from the three given situations.

\section{Development}

\section{Situation I}

The title text "Just Another Day on Aerosol Earth" is presented, along with the Figure (1) [13]. In this textbook - Figure (1), informative scientific, reading where the reader can see that in the text quoted there are several words that are highlighted underlined. The playful part of the situation is to find those words, that hidden lie in Figure (2), which may be located in any order, from top to bottom, left to right, vice versa, and diagonally, all in any direction, i.e. normal reading or backwards. The problem solution is found in Figure (1).

Take a deep breath. Even if the air looks clear, it is nearly certain that you will inhale millions of SOLID PARTICLES and LIQUID DROPLETS. These ubiquitous specks of matter are known as AEROSOLS, and they can be found in the air over oceans, DESERTS, MOUNTAINS, FORESTS, ICE and every ECOSYSTEM in between. 


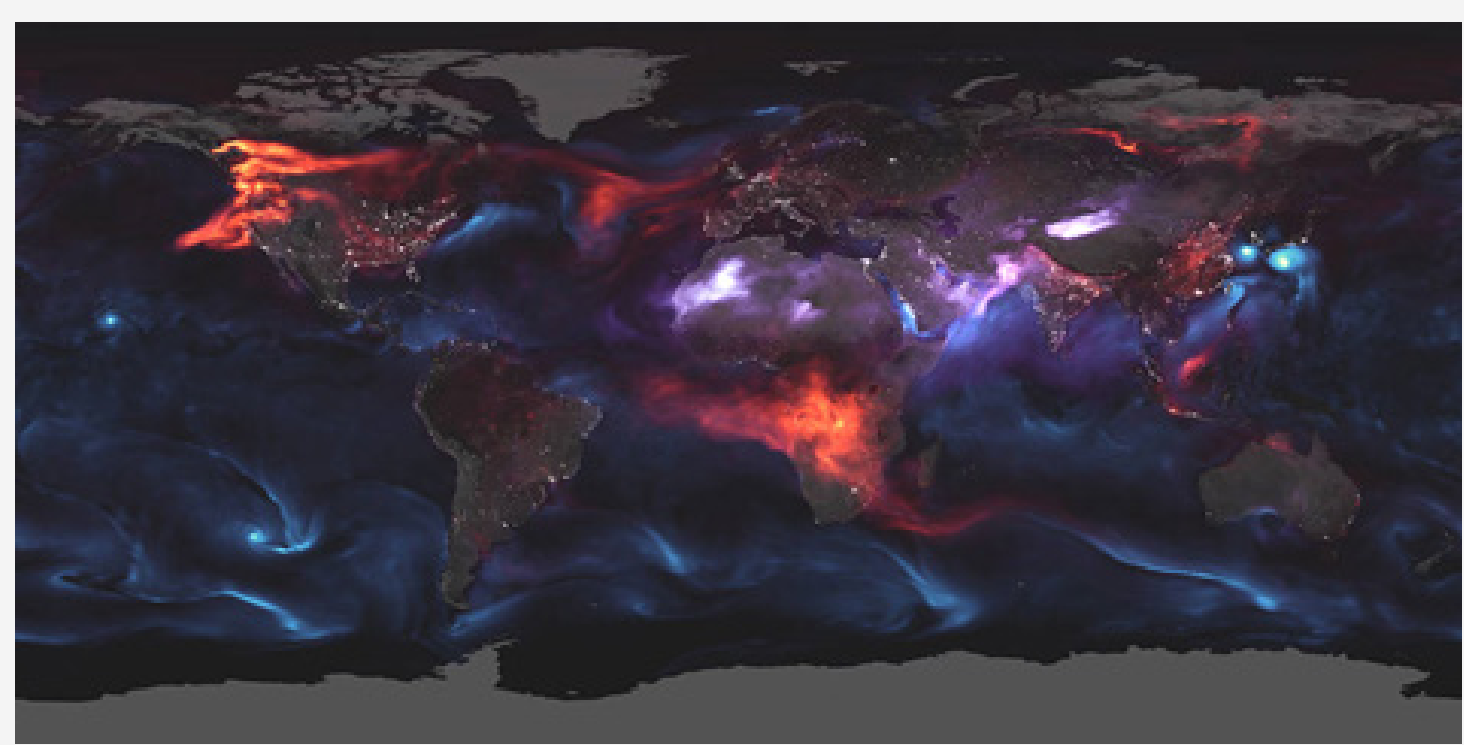

Figure 1: Image of the aerosol in the Earth's atmosphere [13].

If you have ever watched SMOKE billowing from a WILDFIRE, ash erupting from a VOLCANO or dust blowing in the WIND, you have seen aerosols. SATELLITES like NASA's Earth-observing satellites, TERRA, AQUA, AURA and SUOMI NPP, "see" them as well, though they offer a completely different perspective from hundreds of kilometers above Earth's surface. A version of a NASA model called the GODDARD Earth Observing System Forward Processing (GEOS FP) offers a similarly expansive view of the mishmash of particles that dance and swirl through the atmosphere.

The visualization above highlights GEOS FP model output for aerosols on August 23, 2018. On that day, huge plumes of smoke drifted over NORTH AMERICA and AFRICA, three different tropical CYCLONES churned in the PACIFIC OCEAN, and large clouds of dust blew over deserts in Africa and Asia. The STORMS are visible within giant swirls of SEA SALT AEROSOL (blue), which winds loft into the air as part of sea spray. BLACK CARBON PARTICLES (red) are among the particles emitted by fires; vehicle and factory emissions are another common source. Particles the model classified as dust are shown in purple. The visualization includes a layer of night light data collected by the day-night band of the VISIBLE INFRARED Imaging RADIOMETER Suite (VIIRS) on SUOMI NPP that shows the locations of TOWNS and CITIES (Figure 2).

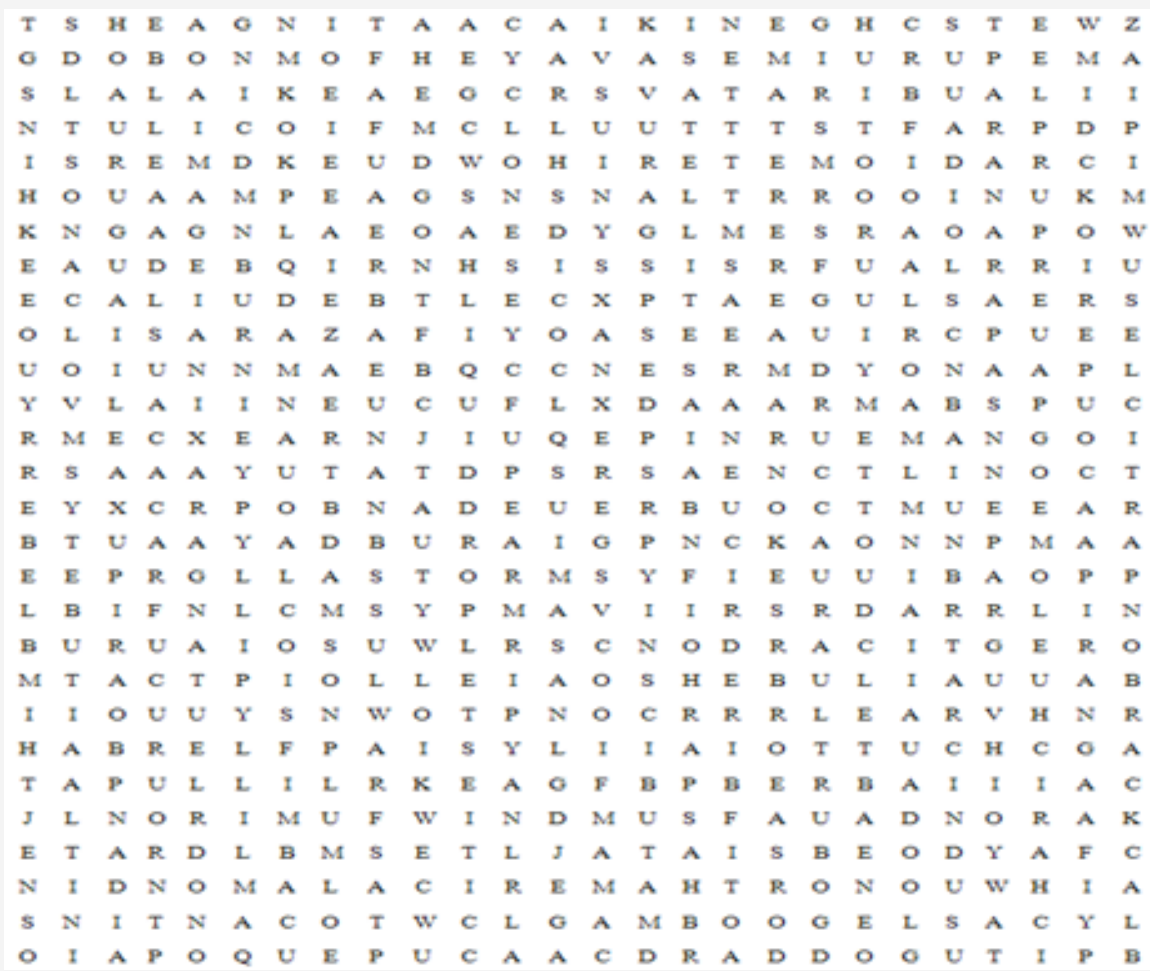

Figure 2: Main diagrams containing all the words to be found, in situations from (I) to (III). 


\section{Situation II}

The name and its meanings of several exotic South American fruits [14] that can be used in cooking are presented. These words and their meanings can be used in a didactic way, informative scientific. The playful part of Situation II is the same as that of Situation I, which is to find those words, which are found in Figure (2). The problem solution is found in Figure (4).

\section{Words to be found in Figure (2)}

- $\quad$ ABIU (Pouteria caimito; Sapotaceae);

- $\quad$ ACKEE (Blighia sapida or Cupania sapida; Sapindaceae);

- American GRAPE: North American species (e.g., Vitis labrusca; Vitaceae) and American-European hybrids are grown where grape (Vitis vinifera) is not hardy and are used as rootstocks;

- $\quad$ ARAZA (Eugenia stipitata);

- $\quad$ BABACO (Carica pentagona; Caricaceae);

- $\quad$ BACURI (Platonia esculenta; Guttiferae);

- BARBADINE (granadilla; maracujá-açu in Portuguese);

- $\quad$ CALAMONDIN (Citrofortunella Microcarpa);

- $\quad$ CHARICHUELO (Garcinia intermedia);

- DAMSON PLUM (Prunus domestica subsp. insititia; Rosaceae);

- $\quad$ DUKU (Lansium domesticum; Meliaceae);

- JABUTICABA (Myrciaria cauliflora; Myrtaceae), also called Brazilian grape tree;

- $\quad$ LILLYPILlY (Acmena spp., Syzygium spp.);

- $\quad$ CARDÓN (Pachycereus pringlei; Cactaceae);

- $\quad$ KARONDA (Carissa carandas; Apocynaceae);

- KORLAN;

- $\quad$ LEUCAENA;

- $\quad$ MANGO (Mangifera indica; Anacardiaceae);

- $\quad$ NONI (Morinda citrifolia; Rubiaceae);

- $\quad$ PEAR, European and Asian species (Pyrus);

- $\quad$ PEQUI (Caryocar brasiliensis; Caryocaraceae);

- $\quad$ RIMU (Dacrydium cupressinum);

- $\quad$ RASPBERRY, several species (genus Rubus);

- TAMARILlO or tree tomato (Cyphomandra betacea; Solanaceae);

- $\quad$ YEW (Taxus baccata; Taxaceae);

- $\quad$ THIMBLEBERRY (Rubus parviflorus);
- ZWETSCHGE (Prunus domestica subsp. domestica; Rosaceae);

- PURPLE GRANADILLA (Passiflora edulis f edulis; Passifloraceae);

- $\quad$ NUNGU (Borassus flabellifer; Arecaceae);

- $\quad$ MORA COMÚN (Rubus adenotrichus);

- GAMBO0GE (Garcinia cambogia; Clusiaceae) [14].

\section{Situation III}

It appears the name and their meanings in various exotic fruits South American as well as places, rivers, drinks, animals, trees, towns, countries, states, etc, who received the name from the TupiGuarani language, which can are found mainly in Brazil [15].

These words can be used in didactic form, scientific information for contemplative reading. The playful part of Situation III is the same as that of Situations I and II, which is to find these words, which are found in Figure (2). The problem solution is found in Figure (5).

The three situations are distinct from each other, they are independent, but it contains an enigma, a message that is contained in Figure (2), hidden from view, and from common reading. When resolving the three different situations together, two messages will appear. Here, two passages from the Christian Bible were given as examples, as "encoded", hidden, encrypted, shorthand messages, but it could be any other message, just being presented as an example.

\section{Words to be found in Figure (2)}

- BAURU - Hot sandwich of bread, ham, cheese and tomato.The sandwich was created at Ponto Chic restaurant, in São Paulo, at the suggestion of a regular called C. P. Neto, who had this nickname because of his hometown, in the interior of the state. The original recipe was with roast beef, tomato, cucumber and cheese mix. The origin of the city's name comes from the Tupi-Guarani: ( $\mathrm{u}$ ) pau (ba) = bathed; $\mathrm{r}-\mathrm{u}$ by $\mathrm{r}-\mathrm{i}=$ water, river; => wetland river.

- SAGÜI - From Tupi Guarani ça-cai = restless eyes. Common name of several species of monkeys of the Callitrichidae family, of small size, with the forelimbs shorter than the posterior ones, with a non-prehensile tail, which occur in South America.

- JATAÍ - from Tupi Guarani ja-atã = hard fruit. Bee species of the Meliponine subfamily. Common name to several plants of the Palmaceae family, more specifically used to designate the palm " Butia Yatay ". Municipality of the state of Goiás.

- AÇAÍ - Also called yasaí. Weeping fruit - fruit from which liquid flows - small brownish coconut, which clumps into the açaí tree (palm tree with a small diameter trunk and thin leaves, which also produces heart of palm). 
- $\quad$ CAPIM - from the Guarani Tupi: caá = leaf; pií = thin, thin

- AIPIM - manioc. It originates from the term tupi ai'pi. Lean root, manioc. In Brazil, it has many names, used in different regions, such as: "Mandioca" originates from the term tupi mãdi'og. "Macaxeira" originates from the Tupi term maka'xera. "Maniva" originates from the term tupi mani'iwa.

\section{- $\quad$ PIRÃO - from Tupi Guarani pirão - the thick porridge.}

More or less thick porridge of manioc flour to eat with stew or stew with fish, meat or roast.

\section{- $\quad$ PITU - it comes from the Tupi language and means}

"dark skin". Called "freshwater shrimp", the pitu is larger than the sea shrimp, almost the size of a lobster. In Pero Vaz de Caminha's Letter of the Discovery of Brazil, "some Indians went to fetch shellfish and only found a few thick and short prawns, among which came a very large and very thick shrimp, which in no time I saw it size". Caminha was where today is the south of Bahia. From Pará to Rio Grande do Sul, the pitu lives in a river of brackish water, mixed with sea water. It tastes like shrimp and is threatened with extinction. In the São Francisco River, pitu fishing was banned indefinitely.

- ABATI - Corn. Also called ibati, auati, auaci, ubati, ubatim. Source language: Tupi-Guarani; flap = hair; ti (nga) = white; => Abati = white hair.

- JABÁ - According to Silveira Bueno, from the tupi yabá 'run away, hide', related to the fact that travelers who were away from home took dried meat as farnel; The word tupi is also attested by Teodoro Sampaio; According to Angenot and others, jabá comes from the Yoruba jabajaba 'beaten meat, sovada' Jabá is used as a synonym for dried meat, beef jerky and sun meat. However, there are differences in the way of preparation.

- The dried meat is manually placed in a little brine, stacked and exposed for a short time to the sun; the final product maintains some characteristics of the original cut. In the jerky, the salting and exposure to the sun are intense, the blankets are practically buried in salt and exposed to the sun for days; the final product has its sensory qualities greatly altered.

- $\quad$ GARUVA - the Tupi Guarani gara by igara-canoa; uba = iba-tree. Garuva = canoe tree (used to make canoes). Yellow wood wild tree. Municipality and city of Santa Catarina.

- UBIRATÃ - Ironwood. de ubira - pau, antan - duro. Very hard wood tree, used for musical instruments. In addition to shade and beauty, it is indicated for reforestation and recovery of degraded areas. Used as a medicine in folk medicine, against anemia, bruises, diabetes and lung infections.

- UIRAPURU - From Tupi Guarani "wirapu 'ru". Uirapuru is the common name for several forest birds, of the order
Passeriformes, of the family of Certhídeos (sub-family Troglodytinae) or of the family of Tyranids (sub-family Priprinae), and can also be called arapuru.

- URUBU - From Tupi-Guarani uru - large bird; bu - negro. Vulture is the generic name for birds of prey in the Carthartidae family, exclusive inhabitants of the American continent.

- URUCU (from the transliterated Tupi uru-ku = "red"), or annatto, is the fruit of the annatto tree (Bixa orellana), a grove of the bixaceae family, native to tropical America, which reaches a height of up to six meters. It has large light green leaves and pink flowers with many stamens. Its fruits are capsules armed by malleable spines, which turn red (reason for the name urucu) when they are ripe. Then they open and reveal small seeds arranged in series, from thirty to fifty per fruit, wrapped in red aryl.

- URUGUAI - From the Tupi-Guarani uruguá - snail; i-river of snails. Rio de Santa Catarina and Rio Grande do Sul which also pass in the country of the same name, Uruguay.

- URUPEMA - Tupi-Guarani uru-pema: cornered, angled or framed basket. Vegetable fiber sieve (Urubá, buriti, carnaúba, etc.) or shallow basket to drain coconut milk, açaí, cassava, bacaba. City and municipality of Santa Catarina, Campos de Lajes area.

- OIAPOQUE - From Tupi Guarani oia-poc $=$ what explodes upon opening. Name of a city and a river that bathes the state of Amapá. In its path it is also called Iaopoco and Iapoc. Between the 16th and 18th centuries, it was called " rio de Vicente Pinzón", in honor of the Spanish navigator, who would have discovered its mouth. It is born in the Serra do Tumucumaque and will flow into the Atlantic Ocean. Along its route it delimits the border between Brazil and French Guiana.

- CAACUPÊ - Capital of Las Cordilleras, department of Paraguay. Beach on the island of Santa Catarina $13 \mathrm{~km}$ from Florianópolis. From Tupi-Guarani: caá = bush; coupe = coast, back; => edge of the bush, behind the bush.

- CAAPIRANGA - From Tupi-Guarani: caá = plant, leaf; piranga $=$ Red $=>$ red leaf. Plant whose macerated leaves give the carajuru (or piranga) paste, the Vermelhão; Diverse plants that show redness in the shoots or leaves; Red Bush, Red Leaf; Amazonas City, Solimões-Tefé Zone.

- CAATINGA - From Tupi-Guarani: caá-t-enga = the thin bush. Type of vegetation that lives in the northeast. These plants can only adapt in places where there is a lot of drought. Caatinga in the language of the Indians means "white forest", due to the lack of water the plants of the caatinga become almost white. The plant is very special for the Northeasterners, it has a little water inside it, but that is still not enough, for people who live in the Northeastern hinterland. 
- PARÁ - From Tupi Guarani to (ba) = vario, multicolor. Brazilian state that has 144 municipalities.

- $\quad$ PARAGUAI - From Tupi Guarani paraguá-i = the headdress river. Paraguay is a country in South America, located between Bolivia, Argentina and Brazil. It has no exit to the sea. It has about 400 thousand $\mathrm{km} .2$ and a population of 6.3 million inhabitants. Its capital is the city of Asunción. Its territory is crossed from north to south by the Paraguay River. The vast majority of the Paraguayan population is of mixed race, of indigenous Guarani and Spaniards.

- PARANÁ - From Tupi Guarani: para + nã = similar to the sea. Paraná is the name of a state and a South American river, which is born from the confluence of the Grande and Paranaíba rivers, between the states of São Paulo, Minas Gerais and Mato Grosso do Sul and has 2,570 km. extension. It marks the border between Brazil and Paraguay, in a stretch of $190 \mathrm{~km}$. Until the mouth of the Iguaçu River; passing this, makes the natural boundary between Argentina and Paraguay.

- $\quad$ XAXIM - from Tupi Guarani Xá = waterfall, Xim = small, means a small waterfall.

- XANXERÊ (from Kaingang) - City and municipality of Santa Catarina, West Zone. In Kaingang, Xanxerê means "Campina da Cascavel", through the combination of the terms xãxã ("rattlesnake") and rê ("campo, campina").

- TANGARÁ - Bird of the family of piprids, which has beautiful plumage with a yellow-orange head. From the Guarani Tupi, they will jump up and down; the skipper.

- $\quad$ TOCANTINS - Tupi tukan (toucan) + tin (nose), where toucan beak, in reference to the confluence of the rivers Araguaia and Tocantins, which has a curved shape that resembles the bird's beak; the region is also called "Bico do Papagaio". State in central Brazil, north of Goiás.

- $\quad$ TATU - Mammals, toothless from the Dasipodídeos family, endowed with a strong articulated carapace, that live in South America. You for too - full-bodied, dense, full-bodied.

- $\quad$ TERERÊ - guarani tereré, sound emitted by the last suck in the drink. Drink made with the infusion of yerba mate. Traditionally it is consumed in a guampa (horn, in quechua) and a "bomb", an adaptation of the fish bone straws used by the Indians. Tereré is consumed in southern Brazil, Mato Grosso do Sul, Paraguay, Argentina and the Andes. It's a cold drink.

- TIETÊ - "Caudal", "bulky", in Tupi. Name of river and municipality of the state of São Paulo.

- $\quad$ CACAU - cacao fruit.The soluble powder made with the cocoa bean is the raw material for chocolate. The word cocoa is used informally as a synonym for money. From Náhuatle: cacauatl $=$ seed .

- BUTIÁ - The term butiá is the common name for palm trees of the genus Butia, native to South America. In general they have medium stipe, with scar of old petioles, long leaves and small edible drupe, with oil seed. From Tupi-Guarani: mbutiai $=$ the palm tree; ibati $=$ tall tree .

- BURITI - Palm tree. Other names: coconut palm-buriti, buritizeiro, muritim, palm-dos-brejos, caranguadaçu, mirror palm, meriti, miriti, wine palm and muriti. From Tupi-Guarani: mbur = food; iti = tall tree; => tall tree of food or life [15-79].

\section{Solutions}

\section{Diagrams}

Figures (3-5)

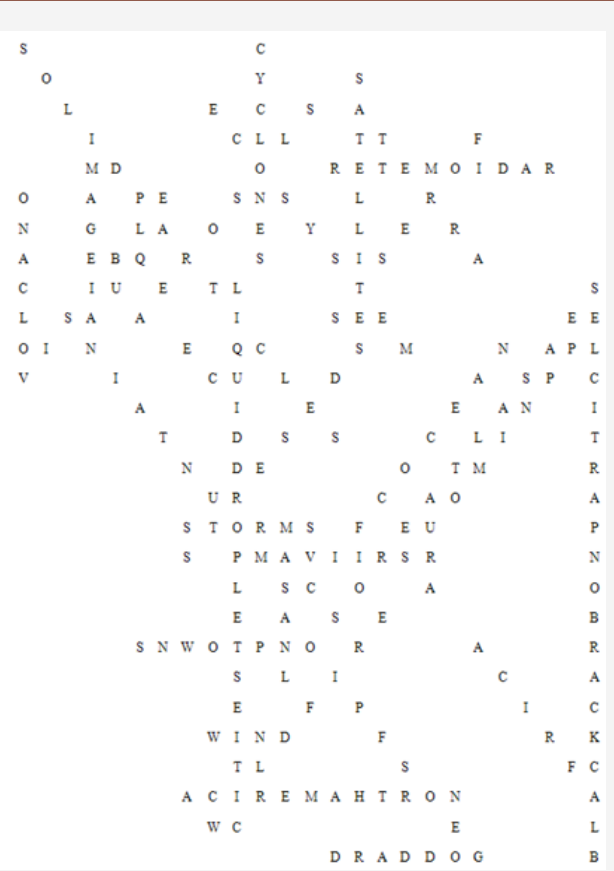

Figure 3: Solution Situation I. 


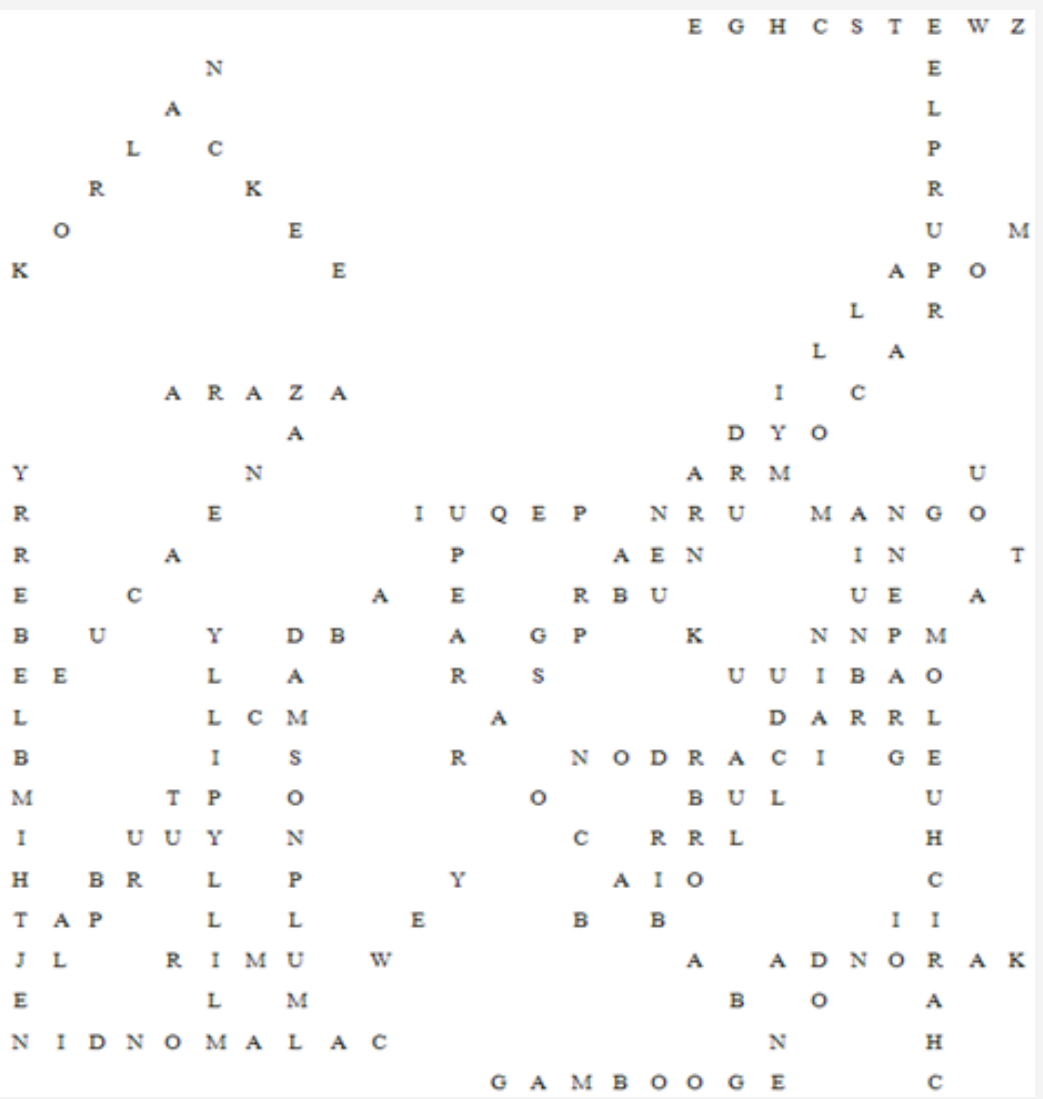

Figure 4: Solution Situation II.

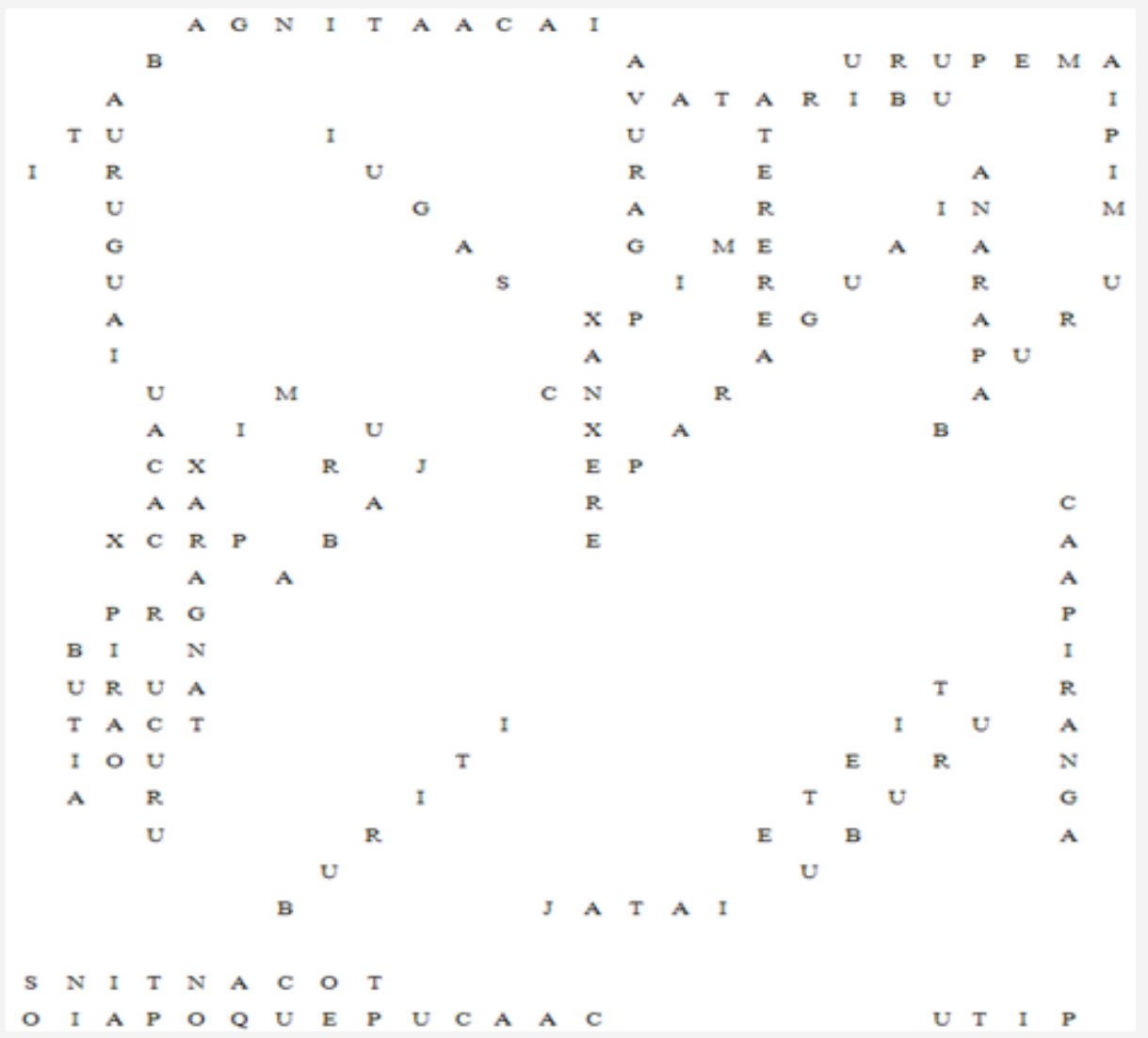

Figure 5: Solution Situation III. 


\section{Enigma solution}

Matthew $\{13: 31\}$ He proposed another parable to them, saying: "The kingdom of heaven is like a grain of mustard seed, which a man took and sowed in his field".

Matthew $\{17: 19\}$ Jesus said to them: "'Because of your unbelief.
Amen I say to you, certainly, if you will have faith like a grain of mustard seed, you will say "to this mountain, 'Move from here to there,' and it shall move. And nothing will be impossible for you" (Figure 6).

soundbible.com/book/holy-bible-pdf-download.pdf.

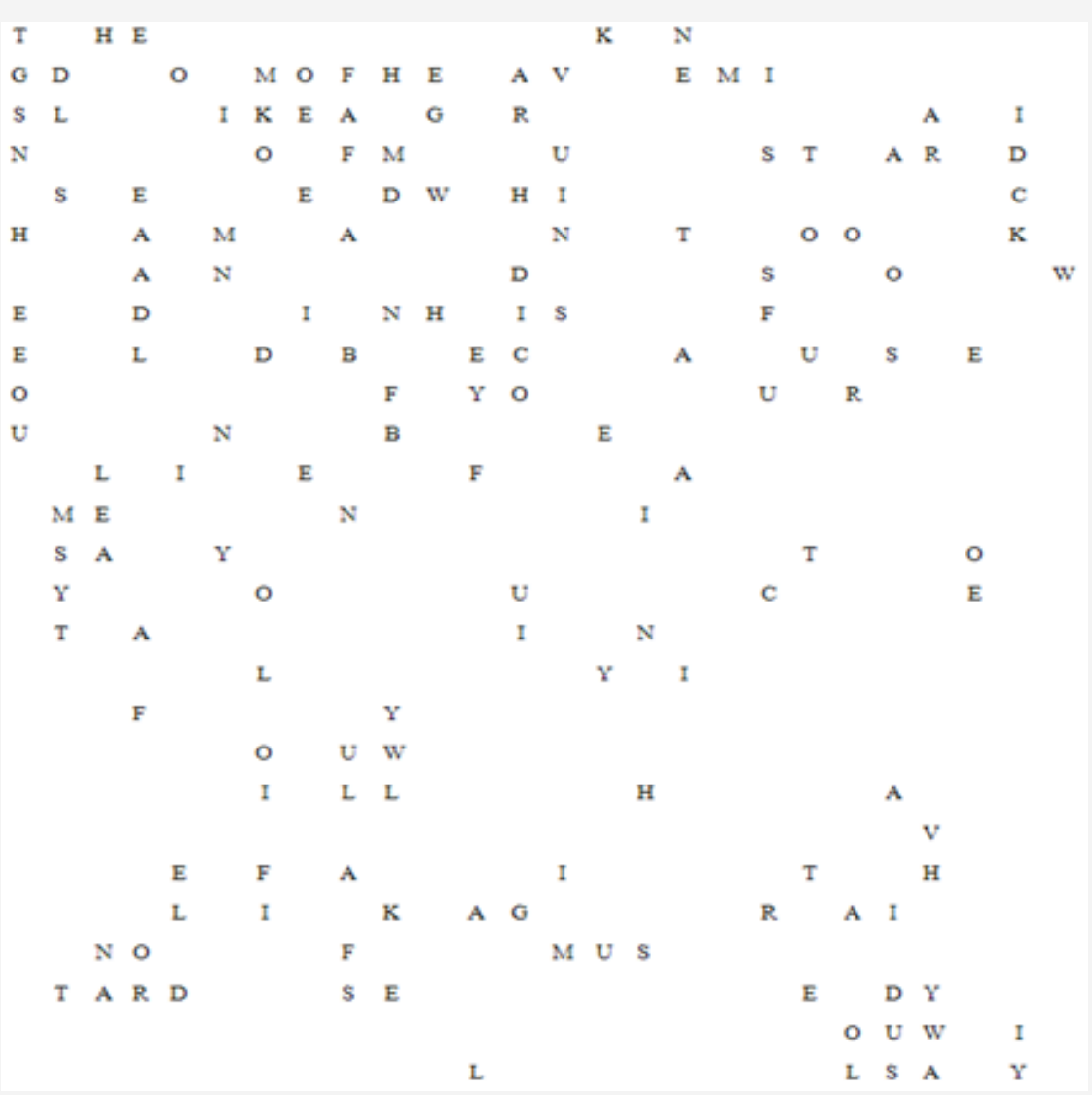

Figure 6: Solution Situation III.

\section{Discussion}

The three situations are distinct from each other, they are independent, but it contains an enigma, a message that is contained in Figure (3), hidden from view, and from common reading. When resolving the three different situations together, two messages will appear. Here, two passages from the Christian Bible were given as examples, as "encoded", hidden, encrypted, shorthand messages, but it could be any other message, just being presented as an example.

\section{Conclusion}

It was shown that the use of a simple ludic, informative, scientific, didactic "game", could contain secret information, coded, directed, to a determined individual, organization, etc. Thus carrying information in a secret character, which would hardly be discovered by any other individual, organization, etc.

\section{Acknowledgement}

None.

\section{Conflicts of Interest}

No conflicts of Interest.

\section{References}

1. HG Liddell, R Scott, HS Jones, R McKenzie, (1984) A Greek-English Lexicon. Oxford University Press.

2. RL Rivest, (1990) “Cryptography”. In J Van Leeuwen (ed). Handbook of Theoretical Computer Science. Elsevier.

3. M Bellare, P Rogaway, (2015) Introduction". Introduction to Modern Cryptography. P. 10.

A. J Menezes, PC van Oorschot, SA Vanstone, (1997) Handbook of Applied Cryptography. 978: 8493-8523.

4. Norman Biggs, (2008) Codes: An introduction to Information Communication and Cryptography, Springer p. 171.

5. (2013) Overview per country. Crypto Law Survey.

6. (2007) UK Data Encryption Disclosure Law Takes Effect. PC World.

7. Steve Ranger, (2016) The undercover war on your internet secrets: How online surveillance cracked our trust in the web. Tech Republic.

8. (2020) (CC BY-SA 3.0) Da Creative Commons . 
9. Jessica Fridrich, M Goljan, D Soukal (2004) Searching for the Stego Key. Proc. SPIE, Electronic Imaging, Security, Steganography, and Watermarking of Multimedia Contents VI. Security, Steganography, and Watermarking of Multimedia Contents VI. 5306:70-82.

10. OJ Pahati, (2007) Confounding Carnivore: How to Protect Your Online Privacy. AlterNet.

11. TY Liu, WH Tsai, (2007) A New Steganographic Method for Data Hiding in Microsoft Word Documents by a Change Tracking Technique, in IEEE Transactions on Information Forensics and Security, 2(1): 24-30.

12. NASA/Joshua Stevens/Adam Voiland, (2018) Just Another Day on Aerosol Earth, NASA, National Aeronautics and Space Administration, Editor: Yvette Smith.

13. (2020) List of culinary fruits.

14. (2018) Dicionario Ilustrado Tupi Gaurani.

15. Ricardo Gobato, Marcia Regina Risso Gobato, Alireza Heidari (2019) Rhodochrosite as Crystal Oscillator. Am J Biomed Sci \& Res 3(2).

16. Ricardo Gobato, Marcia Regina Risso Gobato, Alireza Heidari (2019) Calculation by UFF method of frequencies and vibrational temperatures of the unit cell of the rhodochrosite crystal. International Journal of Advanced Chemistry, 7(2): 77-81.

17. Ricardo Gobato, Marcia Regina Risso Gobato, Alireza Heidari (2019) Rhodochrosite as Crystal Oscillator.

18. Ricardo Gobato, Marcia Regina Risso Gobato, Alireza Heidari (2019) Rhodochrosite as Crystal Oscillator. Am J Biomed Sci \& Res, 3(2).

19. Ricardo Gobato, Marcia Regina Risso Gobato, Alireza Heidari. Rhodochrosite as Crystal Oscillator. viXra.org, Condensed Matter, viXra: 1908. 0295

20. Ricardo Gobato, Marcia Regina Risso Gobato, Alireza Heidari, Abhijit Mitra (2019) Rhodochrosite Optical Indicatrix. Peer Res Nest, 1(3). PNEST.

21. Ricardo Gobato, Marcia Regina Risso Gobato, Alireza Heidari, Abhijit Mitra (2019) Rhodochrosite Optical Indicatrix. viXra.org > Condensed Matter > viXra: 1908

22. Ricardo Gobato, Marcia Regina Risso Gobato, Alireza Heidari, Abhijit Mitra (2019) Hartree-fock Methods Analysis Protonated Rhodochrosite Crystal and Potential in the Elimination of Cancer Cells Through Synchrotron Radiation. Radiation Science and Technology 5(3): 27-36.

23. Ricardo Gobato, Ibtihal Kadhim Kareem Dosh, Alireza Heidari, Abhijit Mitra, Marcia Regina Risso Gobato (2019) Perspectives on the Elimination of Cancer Cells Using Rhodochrossite Crystal Through Synchrotron Radiation, and Absorption the Tumoral and Non-Tumoral Tissues. Arch Biomed Eng \& Biotechnol 3(2).

24. R. Gobato, (2008) Benzocaína, um estudo computacional. Master's thesis, Universidade Estadual de Londrina (UEL),

25. R Gobato, (2017) Study of the molecular geometry of Caramboxin toxin found in star flower (Averrhoa carambola L.). Parana J Sci Edu 3(1): 1-9.

26. R Gobato, A Gobato, DFG Fedrigo (2015) Molecular electrostatic potential of the main monoterpenoids compounds found in oil Lemon Tahiti - (Citrus Latifolia Var Tahiti). Parana J Sci Edu 1(1): 1-10.

27. R Gobato, DFG Fedrigo, A Gobato, Allocryptopine, Berberine (2015) Molecular geometry of the main alkaloids found in the seeds of Argemone Mexicana Linn. Parana J Sci Edu 1(2): 7-16.

28. R Gobato, A Heidari (2018) Infrared Spectrum and Sites of Action of Sanguinarine by Molecular Mechanics and ab initio Methods. International Journal of Atmospheric and Oceanic Sciences 2(1): 1-9.

29. R Gobato, DFG Fedrigo, A Gobato (2015) Molecular geometry of alkaloids present in seeds of mexican prickly poppy. Cornell University Library. Quantitative Biology.

30. R Gobato, A Gobato, DFG Fedrigo (2016) Study of the molecular electrostatic potential of D-Pinitol an active hypoglycemic principle found in Spring flower Three Marys (Bougainvillea species) in the Mm+ method". Parana J Sci Educ 2(4): 1-9.

31. R Gobato, DFG Fedrigo, A Gobato (2015) Avro: key component of Lockheed X-35. Parana J Sci Educ 1(2): 1-6.

32. R Gobato, DFG Fedrigo, A Gobato (2016) LOT-G3: Plasma Lamp, Ozonator and CW Transmitter. Ciencia e Natura 38(1).

33. R Gobato (2016) Matter and energy in a non-relativistic approach amongst the mustard seed and the faith. A metaphysical conclusion. Parana J Sci Educ 2(3): 1-14.

34. R Gobato, A Gobato, D FG Fedrigo (2016) Harnessing the energy of ocean surface waves by Pelamis System. Parana J Sci Educ 2(2): 1-15.

35. R Gobato, A Gobato, DFG Fedrigo (2016) Mathematics for input space probes in the atmosphere of Gliese 581d. Parana J Sci Educ 2(5): 6-13.

36. R Gobato, A Gobato (2016) DFG Fedrigo Study of tornadoes that have reached the state of Parana. Parana J Sci Educ 2(1): 1-27.

37. R Gobato, M Simoes F (2017) Alternative Method of RGB Channel Spectroscopy Using a CCD Reader. Ciencia e Natura 39(2).

38. R Gobato, A Heidari (2017) Calculations Using Quantum Chemistry for Inorganic Molecule Simulation BeLi ${ }_{2} \mathrm{SeSi}$. Science Journal of Analytical Chemistry 5(5): 76-85.

39. MRR Gobato, R Gobato, A Heidari (2018) Planting of Jaboticaba Trees for Landscape Repair of Degraded Area", Landscape Architecture and Regional Planning 3 (1): 1-9.

40. R Gobato (2012) The Liotropic Indicatrix 114 Thesis (Doctorate in Pysics). Universidade Estadual de Londrina, Londrina.

41. R Gobato, A (2017) Heidari Calculations Using Quantum Chemistry for Inorganic Molecule Simulation $\mathrm{BeLi}_{2} \mathrm{SeSi}$. Science Journal of Analytical Chemistry 5(6): 76-85,

42. R Gobato O (2009) Universo dos cristais líquidos", Cadernos PDE, Secretaria de Estado da Educação do Paraná. 2: 1-15.

43. R Gobato, A Heidari (2018) Molecular Mechanics and Quantum Chemical Study on Sites of Action of Sanguinarine Using Vibrational Spectroscopy Based on Molecular Mechanics and Quantum Chemical Calculations. Malaysian Journal of Chemistry 20(1): 1-23.

44. Heidari R, Gobato A Novel Approach to Reduce Toxicities and to Improve Bioavailabilities of DNA/RNA of Human Cancer Cells-Containing Cocaine (Coke), Lysergide (Lysergic Acid Diethyl Amide or LSD), $\Delta 9$ Tetrahydrocannabinol (THC) [(-)-trans- $\Delta$ 9-Tetrahydrocannabinol], Theobromine (Xantheose), Caffeine, Aspartame (APM) (NutraSweet) and Zidovudine (ZDV) [Azidothymidine (AZT)] as Anti-Cancer Nano Drugs by Coassembly of Dual Anti-Cancer Nano Drugs to Inhibit DNA/ RNA of Human Cancer Cells Drug Resistance. Parana Journal of Science and Education 4(6): 1-17, 2018.

45. Heidari R, Gobato (2018) Ultraviolet Photoelectron Spectroscopy (UPS) and Ultraviolet-Visible (UV-Vis) Spectroscopy Comparative Study on Malignant and Benign Human Cancer Cells and Tissues with the Passage of Time under Synchrotron Radiation. Parana Journal of Science and Education 4(6):18-33,

46. R Gobato, A Heidari (2018) Using the Quantum Chemistry for Genesis of a Nano Biomembrane with a Combination of the Elements Be, Li, Se, Si, C and H. J Nanomed Res 7(4): 241-252.

47. SK Agarwal, S Roy, P Pramanick, P Mitra, R Gobato, et al. (2018) Marsilea quadrifolia: A floral species with unique medicinal properties. Parana J Sci Educ 4(5): 15-20.

A. Mitra S, Zaman R, Gobato (2018) Indian Sundarban Mangroves: A potential Carbon Scrubbing System. Parana J Sci Educ 4(4): 7-29.

48. R Gobato M Simoes F (2017) Alternative Method of Spectroscopy of Alkali Metal RGB. Modern Chemistry 5(4): 70-74.

49. DFG Fedrigo, R Gobato, A Gobato (2015) Avrocar: a real flying saucer Cornell University Library. 
50. M Simoes F, AJ Palangana, R Gobato, OR Santos (2012) Micellar shape anisotropy and optical indicatrix in reentrant isotropic-nematic phase transitions. The Journal of Chemical Physics 137: 204905

A. Heidari, R Gobato, Putrescine, Cadaverine, Spermine et al. (2018) Enhanced Precatalyst Preparation Stabilization and Initiation (EPPSI) Nano Molecules Parana Journal of Science and Education (PJSE) 4(5):114.

51. R Gobato, A Heidari, A Mitra (2018) The Creation of $\mathrm{C}_{13} \mathrm{H}_{20} \mathrm{BeLi}_{2} \mathrm{SeSi}$. The Proposal of a Bio-Inorganic Molecule, Using Ab Initio Methods for the Genesis of a Nano Membrane. Arc Org Inorg Chem Sci 3(4).

52. R Gobato A, Heidari A, Mitra (2018) Using the Quantum Chemistry for Genesis of a Nano Biomembrane with a Combination of the Elements Be, $\mathrm{Li}, \mathrm{Se}, \mathrm{Si}, \mathrm{C}$ and $\mathrm{H}$.

53. Heidari, R Gobato (2018) First-Time Simulation of Deoxyuridine Monophosphate (dUMP) (Deoxyuridylic Acid or Deoxyuridylate) and Vomitoxin (Deoxynivalenol (DON)) $((3 \alpha, 7 \alpha)-3,7,15-T r i h y d r o x y-12,13-$ Epoxytrichothec-9-En-8-One)-Enhanced Precatalyst Preparation Stabilization and Initiation (EPPSI) Nano Molecules Incorporation into the Nano Polymeric Matrix (NPM) by Immersion of the Nano Polymeric Modified Electrode (NPME) as Molecular Enzymes and Drug Targets for Human Cancer Cells, Tissues and Tumors Treatment under Synchrotron and Synchrocyclotron Radiations. Parana Journal of Science and Education, 4(6): 46-67.

54. R Gobato, MRR Gobato, A Heidari, A Mitra (2018) Spectroscopy and Dipole Moment of the Molecule C13H20BeLi2SeSi via Quantum Chemistry Using Ab Initio, Hartree-Fock Method in the Base Set CCpVTZ and 6-311G** (3df, 3pd)". American Journal of Quantum Chemistry and Molecular Spectroscopy 2(1): 9-17.

55. R Gobato, MRR Gobato, A (2019) Heidari Raman Spectroscopy Study of the Nano Molecule C13H20BeLi2SeSi Using ab initio and HartreeFock Methods in the Basis Set CC-pVTZ and 6-311G** (3df, 3pd)", International Journal of Advanced Engineering and Science 7(1): 14-35.

56. Heidari, R Gobato (2019) Evaluating the Effect of Anti-Cancer Nano Drugs Dosage and Reduced Leukemia and Polycythemia Vera Levels on Trend of the Human Blood and Bone Marrow Cancers under Synchrotron Radiation. Trends in Res 2(1): 1-8.

57. Heidari, R. Gobato (2019) Assessing the Variety of Synchrotron, Synchrocyclotron and LASER Radiations and Their Roles and Applications in Human Cancer Cells, Tissues and Tumors Diagnosis and Treatment. Trends in Res 2(1): 1-8.

58. Heidari, R Gobato (2019) Pros and Cons Controversy on Malignant Human Cancer Cells, Tissues and Tumors Transformation Process to Benign Human Cancer Cells, Tissues and Tumors", Trends in Res 2(1): $1-8$.

59. Heidari, R Gobato (2019) Three-Dimensional (3D) Simulations of Human Cancer Cells, Tissues and Tumors for Using in Human Cancer Cells, Tissues and Tumors Diagnosis and Treatment as a Powerful Tool in Human Cancer Cells, Tissues and Tumors Research and Anti-Cancer Nano Drugs Sensitivity and Delivery Area Discovery and Evaluation. Trends in Resn 2(1): 1-8.

60. Heidari, R Gobato (2019) Investigation of Energy Production by Synchrotron, Synchrocyclotron and LASER Radiations in Human Cancer Cells, Tissues and Tumors and Evaluation of Their Effective on Human Cancer Cells, Tissues and Tumors Treatment Trend", Trends in Res 2(1): $1-8$.
61. Heidari, R Gobato (2019) High-Resolution Mapping of DNA/RNA Hypermethylation and Hypomethylation Process in Human Cancer Cells, Tissues and Tumors under Synchrotron Radiation. Trends in Res 2(2): 1-9.

62. R Gobato, MRR Gobato, A Heidari (2019) Storm Vortex in the Center of Paraná State on June 6, 2017: A Case Study. Sumerianz Journal of Scientific Research 2(2): 24-31.

63. R Gobato, MRR Gobato, A Heidari (2019) Attenuated Total ReflectionFourier Transform Infrared (ATR-FTIR) Spectroscopy Study of the Nano Molecule C13H20BeLi2SeSi Using ab initio and Hartree-Fock Methods in the Basis Set RHF/CC- pVTZ and RHF/6-311G** (3df, 3pd): An Experimental Challenge to Chemists. Chemistry Reports 2(1): 1-26.

64. R Gobato, MRR Gobato, A Heidari, A Mitra (2019) New NanoMolecule Kurumi-C13H 20BeLi2SeSi/C13H19BeLi2SeSi, and Raman Spectroscopy Using ab initio, Hartree-Fock Method in the Base Set CCpVTZ and 6-311G** (3df, 3pd). J Anal Pharm Res 8(1): 1-6.

65. R Gobato, MRR Gobato, A Heidari (2019) Evidence of Tornado Storm Hit the Counties of Rio Branco do Ivaí and Rosario de Ivaí, Southern Brazil. Sci Lett 7 (1): 9.

66. Moharana Choudhury, Pardis Fazli, Prosenjit Pramanick, Ricardo Gobato, Sufia Zaman, et al (2019) Sensitivity of the Indian Sundarban mangrove ecosystem to local level climate change. Parana Journal of Science and Education 5(3): 24-28.

67. Arpita Saha, Ricardo Gobato, Sufia Zaman, Abhijit Mitra (2019) Biomass Study of Mangroves in Indian Sundarbans: A Case Study from Satjelia Island", Parana Journal of Science and Education. 5(2): 1-5.

68. Nabonita Pal, Arpan Mitra, Ricardo Gobato, Sufia Zaman, Abhijit Mitra (2019) Natural Oxygen Counters in Indian Sundarbans, the Mangrove Dominated World Heritage Site. Parana Journal of Science and Education 5(2); 6-13.

69. Ricardo Gobato, Victoria Alexandrovna Kuzmicheva, Valery Borisovich Morozov (2019) Einstein's hypothesis is confirmed by the example of the Schwarzschild problem. Parana Journal of Science and Education, 5(1): 1-6.

70. Sufia Zaman, Ricardo Gobato, Prosenjit Pramanick, Pavel Biswas, Uddalok Chatterjee, et al. (2018) Water quality of the River Ganga in and around the city of Kolkata during and after Goddess Durga immersion. Parana Journal of Science and Education 4(9): 1-7.

71. Sufia Zaman, Utpal Pal, Ricardo Gobato, Alekssander Gobato, Abhijit Mitra (2018) The Changing Trends of Climate in Context to Indian Sundarbans. Parana Journal of Science and Education 4(7): 24-28.

72. Suresh Kumar Agarwal, Sitangshu Roy, Prosenjit Pramanick, Prosenjit Mitra, Ricardo Gobato eta al. (2018) Parana Journal of Science and Education 4( 5): 15-20.

73. Ricardo Gobato, Marcia Regina Risso Gobato (2018) Evidence of Tornadoes Reaching the Countries of Rio Branco do Ivai and Rosario de Ivai. Climatol Weather Forecasting 6: 4.

74. Ricardo Gobato (2019) New Nano-Molecule Kurumi and Raman Spectroscopy using ab initio, Hartree-Fock Method Am J Biomed Sci \& Res 2(4). 